\title{
PELATIHAN APLIKASI ADMINISTRASI MANAJEMEN SAMPAH PADA BANK SAMPAH RT. 04 RW. 07 DESA LANGENHAJO-GROGOL-SUKOHARJO
}

\author{
Nani Irma Susanti ${ }^{1}$, Winarno $^{2}$, Endang Saryanti ${ }^{3}$ \\ STIE Adi Unggul Bhirawa Surakarta \\ Email: niss_irma@stie-aub.ac.id
}

\begin{abstract}
ABSTRAK
Sebanyak 25 anggota PKK RT 04 RW 07 Desa Langenharjo Kecamatan Grogol Sukoharjo hadir dalam Pelatihan Aplikasi Manajemen Setoran Sampah pada hari Minggu 14 Juli 2019. Diharap dengan pelatihan ini, penguasaan ketrampilan anggota PKK RT 04 RW 07 Desa Langenharjo Kecamatan Grogol Sukoharjo dapat lebih meningkatkan semangat anggota PKK, terutama pengurus bank Sampah. Laporan keuangan dari hasil setoran sampah harus transparan, sehingga tidak menimbulkan sikap saling curiga antar anggota PKK. Anggota PKK menjadi semakin semangat karena mereka sekarang menyadari jika sampah dikelola dengan baik dan benar malah akan menjadi sumber uang. Aplikasi Manajemen Sampah menggunakan program Microsoft excel yang mudah dan dapat digunakan dengan offline, sehingga diharapkan pengurus semakin dimudahkan dalam mencatat administrasi setoran sampah warga, baik anggota PKK maupun warga sekitar.
\end{abstract}

Kata Kunci: Aplikasi offline, Manajemen Keuangan Bank Sampah, Microsoft Excel, Manajemen Administrasi Bank Sampah

\section{A. ANALISA SITUASI}

Menindak lanjuti kegiatan PKM yang telah dilakukan oleh tim. Agar kegiatan pengelolaan sampah dapat berjalan, tim mencoba untuk memberikan motivasi kepada anggota PKK agar tetap semangat dalam menjaga lingkungan. Tidak mudah memberikan pelatihan kepada anggota PKK di daerah perumahan dengan tingkat ekonomi mapan. Tim mencoba memasukan teknologi dalam proses administrasi pengumpulan sampah. Dengan mencoba menambahkan aplikasi Microsoft Excel dalam pencatatan administrasi pengumpulan sampah.

Sukoharjo adalah kota yang sangat nyaman, kota yang asri dan menjadi dambaan seperti slogan dari Sukoharjo itu sendiri yaitu Sukoharjo Makmur. Sukoharjo MAKMUR juga mempunyai arti atau kepanjangan dari Maju Aman Konstitusional Mantap Unggul Rapi. Disamping kota Sukoharjo nyaman, orang-orang yang tinggal di Sukoharjo juga ramah dan menyenangkan. Sukoharjo terkenal dengan hasil pertanian, kerajinan, serta produksi jamu.

Kabupaten Sukoharjo mempunyai nama sebutan (julukan) yang cukup terkenal, antara lain: Kota Makmur, Kota Tekstil, Kota Gamelan, The House of Souvenir, Kota Gadis (perdagangan, pendidikan, industri, dan bisnis), Kabupaten Jamu, Kabupaten Pramuka, serta Kabupaten Batik. 
Kota mandiri yang pertama di Jawa Tengah bernama Solo Baru, yang dikembangkan oleh PT

Pondok Solo Permai (PSP). Perencanaan pengembangan dan pembangunan kawasan Solo Baru yang mempunyai luas area kurang lebih 200 hektare, lebih mengarah sebagai kawasan pemukiman, atau lebih tepat dikatakan sebagai kota satelit. Pemilihan lokasi di Kabupaten Sukoharjo oleh PSP bukan tanpa pertimbangan yang matang. Penggagas konsep Solo Baru adalah Kunto Hardjono, yang saat itu menjabat sebagai direktur utama PSP. Namun, tidak jarang ada yang menyebut nama Handoko, bos PT Batik Keris, sebagai pemilik obsesi itu. Awal perencanaan pengembangan dan pembangunan kawasan Solo Baru lebih mengarah sebagai kawasan pemukiman semata, atau lebih tepat dikatakan sebagai kota satelit. "Karena sesuai dengan sebutannya kota satelit, adalah penyedia hunian yang memiliki akses baik dengan lokasi industri. Dengan perkataan lain, warga dengan masyarakatnya masih tergantung kepada kota induk yang lebih besar. Membangun Solo Baru sebagai kota mandiri tidak mudah. Salah satu faktornya karena kedekatan lokasi Solo Baru dengan kota Solo, unsur kedekatan ini yang yang merangsang ke arah ketergantungan Solo Baru kepada kota Surakarta. Sehingga, dengan kedekatan ini membuat masyarakat Solo Baru bolak-balik ke Surakarta untuk memenuhi kebutuhan hidupnya. Fasilitas penunjang adanya sarana pendidikan berkelas seperti, TK-SD, Tarakanika dan Akademi Teknik Warga. Juga untuk kesehatan ada rumah sakit Dr Oen Solo Baru, sarana belanja seperti Alfa Gudang Rabat, sarana olah raga GOR Solo Baru dan kolam renangnya, obyek wisata air, Pandawa Lima Water Park. Saat ini, jaringan jalan yang dimiliki Kabupaten Sukoharjo telah mencapai total panjang $523 \mathrm{~km}$, yang terdiri dari jalan dalam kota $(65,5$ $\mathrm{km}$ ) dan jalan luar kota $(457,5 \mathrm{~km})$. Untuk jenis pemakaian jalan, sekitar $506 \mathrm{~km}$ berupa jalan aspal dan 17 $\mathrm{km}$ jalan krikil dengan kondisi baik sepanjang $87 \mathrm{~km}$, sedang $110 \mathrm{~km}$, dan yang masih dalam perbaikan sepanjang $326 \mathrm{~km}$. Adanya pusat perbelanjaan modern The park, Hartono Mall, Hartono Trade Center, Carrefour, beberapa hotel seperti, Hotel Brother 1 dan 2. Hotel Western, Hotel Aston, Fave Hotel, Best Western Hotel dan banyak rumah makan serta pedagang kaki lima sebagai penunjang berdirinya industri di Sukoharjo.

Begitu sibuk dan ramainya kegiatan di daerah Solo baru yang merupakan bagian dari desa Langenharjo sehingga, jika 1 hari setiap manusia baik tua muda, sakit sehat perempuan laki-laki rata-rata mengahsilkan $2 \mathrm{~kg}$ sampah dari aktifitasnya, maka jumlah sampah yang harus dikelola oleh pemerintah, khususnya di kecamatan Grogol yang memiliki jumlah penduduk sebanyak 121.210, yang terdiri dari 60.137 perempuan dan 61.073 laki-laki. Sedangkan untuk penduduk Langenharjo ada 8.558 jiwa yang terdiri dari 4.250 laki-laki dan 4.308 perempuan. Dengan jumlah sampah yang dihasilkan setiap jiwa ratarata $2 \mathrm{~kg}$ setiap hari, baik wanita maupun pria, baik sehat maupun sakit, baik dewasa maupun balita, maka masyarakat mau tidak mau harus mengelola sampah mereka sendiri. Pemerintah tidak akan mampu mengelola sampah yang dari hari ke hari semakin menumpuk, jika tidak dikelola dengan baik dan benar. Perlu adanya upaya pengelolahan yang profesional agar sampah organik bisa menjadi sesuatu yang menghasilkan sesuatu yang berguna dan mempunyai nilai ekonomis. ( $\mathrm{Si}, 2013)$.

Di daerah perkotaan, sebagian besar masyarakat membuang sampah di depan rumah di tempat sampah yang sudah disediakan. Lingkungan RT mengkoordinir sampah RT dengan menarik iuran setiap bulan. Sampah diambil oleh petugas kelurahan setiap hari atau setiap waktu yang sudah disepakati. Saat ini pengambilan sampah dikelola oleh swasta, karena prospek mengelola sampah saat ini sangat menggiurkan dan menjanjikan. Baik sampah organik maupun anorganik, jika dikelola dengan baik dan benar akan memberikan tambahan penghasilan bagi pengelolanya. Sampah organik baik musim hujan ataupun kemarau selalu menjadi masalah. Sehingga perlu diolah agar kotor dan bau yang menjadi masalah selama ini dapat teratasi dan bernilai guna, selain berdampak bersih pada lingkungan. 


\section{B. IDENTIFIKASI MASALAH}

Dari latar belakang di atas maka identifikasi masalah yang akan dijadikan kegiatan tim PKM adalah:

a. Memberikan motivasi kepada sebagian anggota PKK yang sudah mulai peduli kepada pengeloaan sampah dengan memilah sampah dari rumah.

b. Administrasi penerimaan sampah yang telah dipilah di rumah, masih manual, sedangkan Pendidikan anggota PKK terutama pengurusnya minimal setingkat SMA, sehingga untuk lebih memotivasi anggota dan pengurus PKK dibuatkan setoran sampah dengan menggunakan Microsoft Excel, selain lebih memudahkan, mengajarkan dan melatih anggota PKK yang sudah lanjut untuk menggunakan teknologi, bagi anggota yang muda agar menjaga ilmunya terutama dibidang teknologi, terutama program Microsoft Excel.

c. Diharapkan dengan menggunakan program Microsoft Excel dalam administrasi pengeloaan sampah membuat anggota dan pengurus semakin semangat.

C. PERUMUSAN MASALAH

Bagaimana administrasi pengelolaan sampah dengan menggunakan program Microsoft Excel?

\section{TUJUAN DAN MANFAAT}

1. TUJUAN

Untuk mempermudah administrasi pengelolaan sampah rumah tangga dengan menggunakan program Microsoft Excel oleh pengurus Bank Sampah RT. 04 RW. 7

2. MANFAAT

a. Administrasi pengelolaan sampah rumah tangga yang sudah dipilah di tingkat rumah menjadi semakin baik

b. Menghindari praduga buruk, karena sekarang sampah sudah bisa menjadi uang. Mengelola uang dalam organisasi dibutuhkan syarat yang transparan.

\section{E. TINJAUAN PUSTAKA}

a. Manajemen Bank Sampah,

Pengertian Bank Sampah Bank sampah lahir dari program Jakarta Green and Clean yaitu salah satu cara pengelolaan sampah skala rumah tangga, yang menitik beratkan pada pemberdayaan masyarakat dalam mengelola sampah rumah tangga. Bank sampah adalah tempat menabung sampah yang telah terpilih menurut jenis sampah, sampah yang ditabung pada bank sampah adalah sampah yang mempunyai nilai ekonomis. Cara kerja bank sampah pada umumnya hampir sama dengan bank lainnya, ada nasabah, pencatatan pembukuan dan manajemen pengelolaannya, apabila dalam bank yang biasa kita kenal yang disetorkan nasabah adalah uang akan tetapi dalam bank sampah yang disetorkan adalah sampah yang mempunyai nilai ekonomis, sedangkan pengelola bank sampah harus orang kreatif dan inovatif serta memiliki jiwa kewirausahaan agar dapat meningkatkan pendapatan masyarakat. Sistem kerja bank sampah pengelolaan sampahnya berbasis rumah tangga, dengan memberikan reward kepada yang berhasil memilah dan menyetorkan sejumlah sampah (Unilever Green \& Clean, 2010). 
Peran Bank Sampah

Peran Bank Sampah terdapat dalam teori pertukaran. "Teori pertukaran menekankan kepada sosiologi perilaku agar memusatkan perhatian pada hubungan antara pengaruh perilaku seorang aktor terhadap lingkungan dan dampak lingkungan terhadap aktor.

Hubungan ini adalah dasar untuk pengkondisian operan atau proses belajar yang melalui perilaku disebabkan oleh konsekuensinya "(Ritzer dan Douglas, 2007). Teori ini berkembang pada rewads and punishment. Bank sampah merupakan institusi lokal yang kekuasaannya tidak begitu besar. Bank Sampah tidak dapat melakukan punishment kepada masyarakat, sehingga Bank Sampah harus menggunakan system rewads. Proses penyadaran lingkungan melalui tabungan sampah yang dinilai dengan uang atau Rupiah merubah paradigma masyarakat tentang sampah. Sampah yang seharusnya dibuang menjadi bermanfaat.

Analisis Sistem

Menganalisis sistem merupakan tahapan dalam menganalisis kebutuhan-kebutuhan sistem. Menurut Kendall \& Kendall (2003: 13), perangkat atau Teknik untuk menentukan kebutuhan system adalah dengan menggunakan diagram aliran data untuk menyusun daftar input, proses, dan output fungsi bisnis dalam bentuk grafik terstruktur. Dari diagram aliran data, dikembangkan suatu kamus data berisikan daftar seluruh item data yang digunakan dalam sistem beserta spesifikasinya berupa tipe data atau constraintnya.

Syarat Bank Sampah
a. Pemilahan
b. Pencatatan
c. Pengurus
d. Nasabah/anggota masyarakat
e. Penjualan
f. Pemanfaatan Hasil
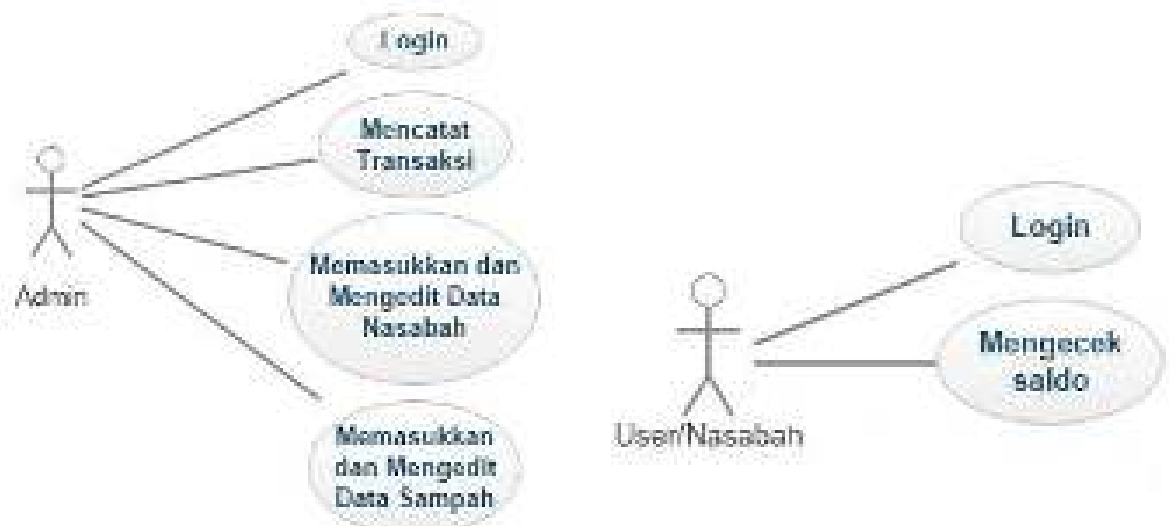


\begin{tabular}{|cl|l|c|}
\hline No. & Jenis Sampah & Nama Sampah & Harga/Kg \\
\hline 1. & Logam & Alumunium & 9000 \\
\hline 2. & Logam & Besi & 3000 \\
\hline 3. & Logam & Metal & 2400 \\
\hline 4. & Non-logam & Plastik & 1400 \\
\hline 5. & Non-logam & Kertas HVS & 1600 \\
\hline 6. & Non-logam & Kertas koran & 1600 \\
\hline 7. & Non-logam & Kardus & 1400 \\
\hline 8. & Non-logam & Gelas / kaca & 350 \\
\hline 9. & Non-logam & Botol plastik & 400 \\
\hline 10. & Non-logam & Botol kaca & 700 \\
\hline 11. & Logam & Kuningan & 7250 \\
\hline 12. & Non-logam & Kaca & 2750 \\
\hline
\end{tabular}

\section{Desain (Design)}

Proses desain dilakukan untuk mengubah kebutuhan menjadi bentuk karakteristik yang dapat dimengerti perangkat lunak sebelum dimaulai penulisan program. Desain ini harus di dokumentasikan dengan baik dan menjadi bagian konfigurasi perangkat lunak. Proses ini meliputi: Pembuatan flowchart, Data Flow Diagram dan Normalisasi Data.

b. Manajemen Keuangan Sampah

Simulasi Sistem Bank Sampah

a. Nasabah datang membawa sampah yang sudah dipilah dan buku tabungan

b. Nasabah mengisi presensi

c. Pengurus mencatat setoran sampah

d. Menimbang sampah

e. Nasabah menyerahkan buku tabungan

f. Pengurus mencatat di buku besar

Buku Administrasi

Pengurus

a. Buku Register

b. Buku Besar

Nasabah

a. Buku Tabungan

b. Buku Bantu/Girik Catatan

Buku Besar Pengurus

Berisi catatan:

a. Berat Sampah

b. Rekap Penjualan Nilai Sampah (Rp) 


\begin{tabular}{|c|c|c|c|c|c|c|c|c|c|c|c|c|c|}
\hline \multirow[t]{2}{*}{ No } & \multirow[t]{2}{*}{ Nama } & \multirow{2}{*}{$\begin{array}{c}\text { No } \\
\text { Induk }\end{array}$} & \multirow{2}{*}{$\begin{array}{c}\text { Tgl. } \\
\text { Penjualan }\end{array}$} & \multicolumn{2}{|c|}{ Kertas } & \multicolumn{2}{|c|}{ Kardus } & \multicolumn{2}{|c|}{ Botol } & \multicolumn{2}{|c|}{ Plastik } & \multicolumn{2}{|c|}{ Besi } \\
\hline & & & & $\mathrm{Kg}$ & $\mathrm{Rp}$ & $\mathrm{Kg}$ & $\mathrm{Rp}$ & $\mathrm{Kg}$ & $\mathrm{Rp}$ & $\mathrm{Kg}$ & $\mathrm{Rp}$ & $\mathrm{Kg}$ & $\mathrm{Rp}$ \\
\hline
\end{tabular}

Buku Register untuk Pengurus

Berisi data nasabah

\begin{tabular}{|l|l|l|l|l|}
\hline No & No. Induk & Nama & Alamat & Jumlah KK \\
\hline & & & & \\
\hline
\end{tabular}

Buku Bantu Nasabah

Nasabah mencatat jenis sampah yang dibawa

Berisi:

1. List Harga

2. Berat Sampah

3. Nilai Sampah setelah ditimbang

4. No. Induk dan Data Nasabah

Pengembangan Sistem Bank Sampah

- Unit Usaha Simpan Pinjam

- Unit sembako

- Unit modal Usaha

c. Microsoft Excel

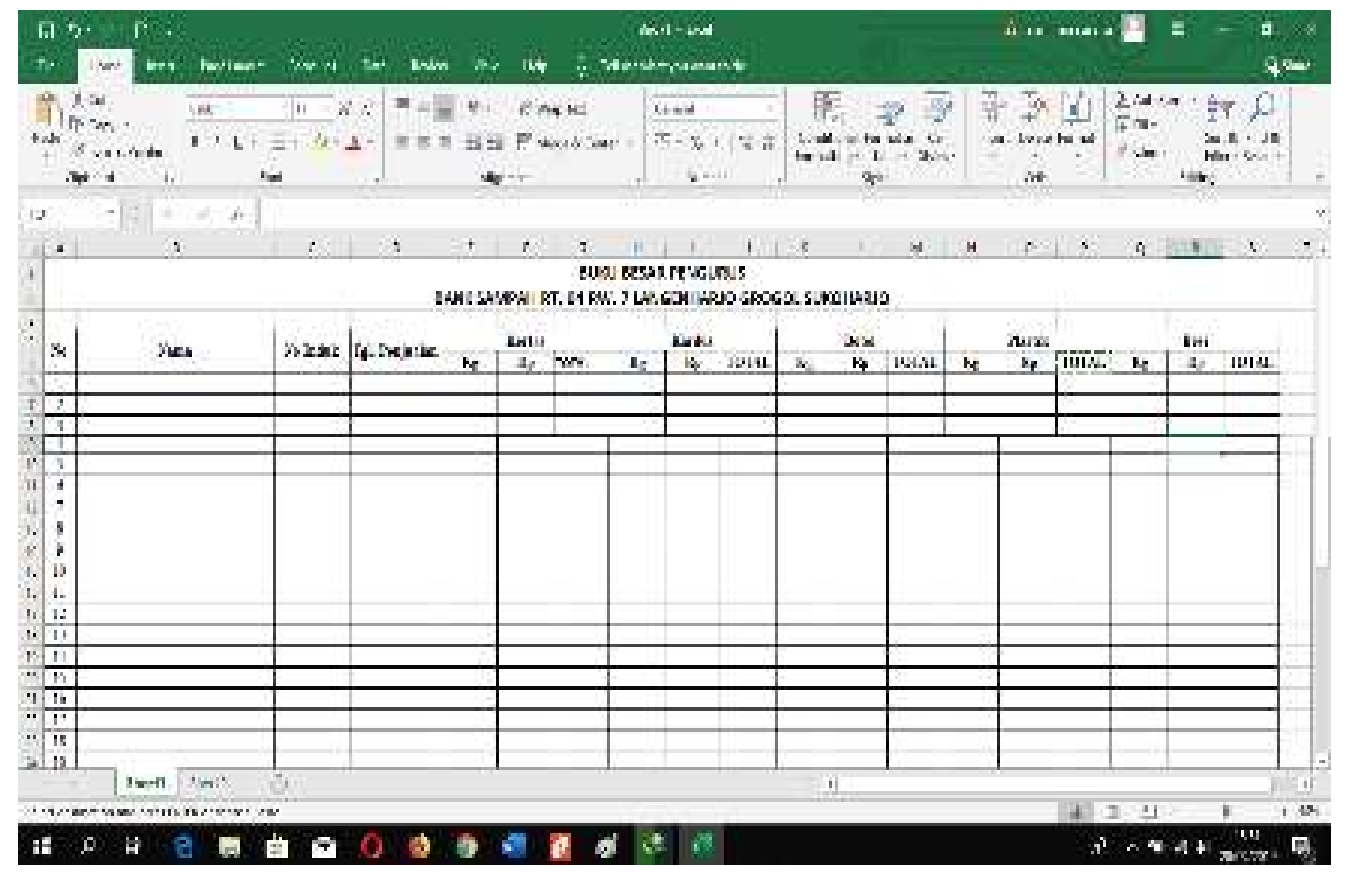


Buku Register untuk Pengurus

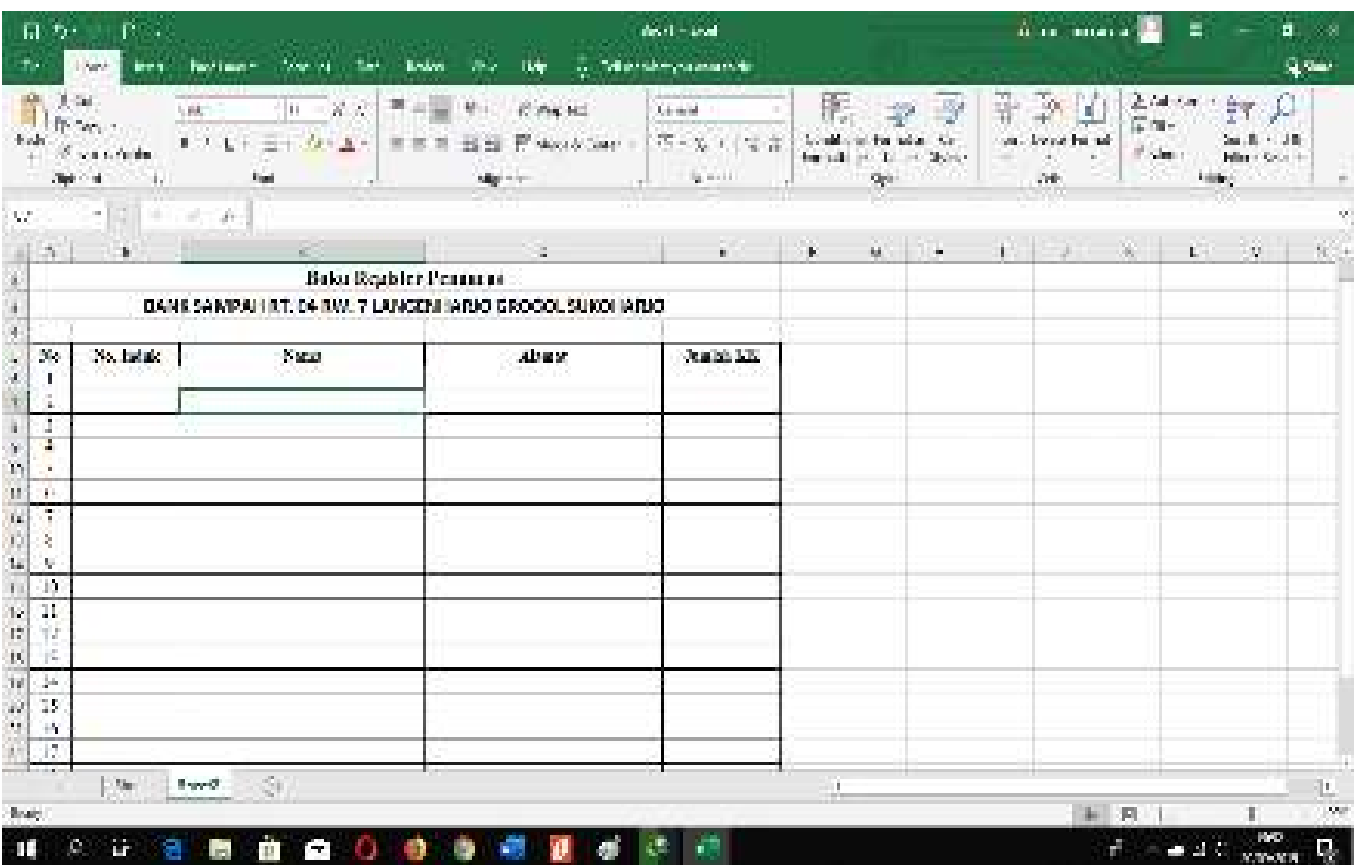

F. METODE

Metode yang Digunakan:

1. Bersifat pemberian materi secara teoritis

2. Pelatihan

3. Penyelesaian Kasus dari Lapangan

Kegiatan pelatihan yang diselenggarakan menggunakan metode survei, pre-test dan posttest, ceramah, praktek pelatihan serta diskusi-konsultasi. Survei dilakukan dengan wawancara 'user need assesment' kepada pengurus Anggota dan anggota PKK RT 04 RW 07 Desa Langenharjo Kecamatan Grogol Sukoharjo, dasarnya untuk mendapatkan data, jenis dan kebutuhan anggota Anggota anggota PKK RT 04 RW 07 Desa Langenharjo Kecamatan Grogol Sukoharjo dalam memperlakukan sampah rumah tangga, terutama sampah organic.

Metode ceramah, praktek pelatihan serta diskusi-konsultasi dilakukan selama kegiatan pelatihan. Secara rinci metode yang dilakukan adalah sebagai berikut:

\section{Ceramah}

Penjelasan diberikan kepada peserta dalam hal masalah sampah dan dampak sampah jika tidak dikelola dengan baik dan benar sehingga dapat meningkatkan kesejahteraan mereka.

\section{Penjelasan - Sosialisasi}

Disertai langsung dengan praktek pembuatan kompos 
3. Selama pelatihan peserta difasilitasi

Dalam melakukan diskusi-konsultasi untuk membahas permasalahan yang timbul dalam permasalahan menyalakan laptop, membuka program Microsoft excel, menggunakan menu dalam excel, membuat laporan dalam bentuk chart.

\section{Tempat Pengabdian}

Di rumah ibu Rudi Jl. Gelatik III RT 04 RW 07 Desa Langenharjo Kecamatan Grogol Sukoharjo

\section{Pendamping Pemateri}

Dua (2) orang mahasiswa terdiri dari Jenjang S-1 Manajemen.

\section{G. HASIL}

1. $100 \%$ peserta yang diundang $75 \%$ hadir dalam pelatihan.

2. Terlaksananya seluruh kegiatan.

3. Pernyataan kepuasan dari anggota dan pengurus PKK RT 04 RW 07 Desa Langenharjo Kecamatan Grogol Sukoharjo dan pemerintah daerah setempat.

4. Program aplikasi manajemen sampah berbasis Microsoft Excel

\section{H. PEMBAHASAN}
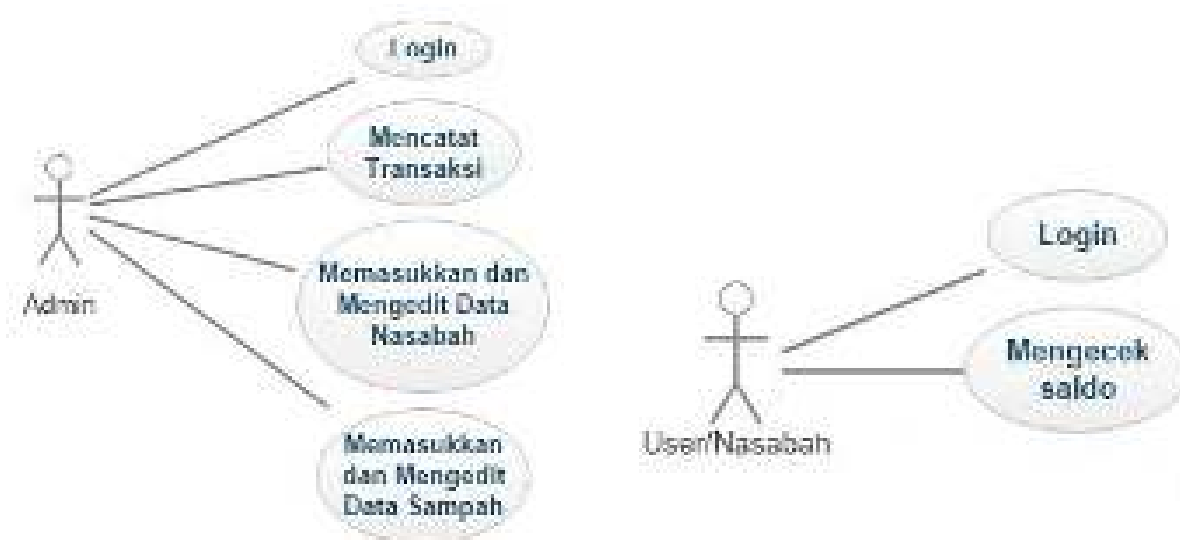

1. Anggota PKK RT. 04 RW. 07 sepakat menggunakan aplikasi manajemen sampah berbasis Microsoft Excel dibandingkan dengan aplikasi berbasis web \& mobile yang bertujuan untuk mendukung kegiatan operasional Bank Sampah secara nasional.

2. Harga Sampah selalu diupdate oleh pengurus sampah. 
Tabel 1. Daftar Jenis Sampah

\begin{tabular}{|c|l|l|c|}
\hline No. & Jenis Sampah & Nama Sampah & Harga/Kg \\
\hline 1. & Logam & Alumunium & 9000 \\
\hline 2. & Logam & Besi & 3000 \\
\hline 3. & Logam & Metal & 2400 \\
\hline 4. & Non-logam & Plastik & 1400 \\
\hline 5. & Non-logam & Kertas HVS & 1600 \\
\hline 6. & Non-logam & Kertas koran & 1606 \\
\hline 7. & Non-logam & Kardus & 1400 \\
\hline 8. & Non-logam & Gelas/ kaca & 350 \\
\hline 9. & Non-logam & Botol plastik & 400 \\
\hline 10. & Non-logam & Botol kaca & 700 \\
\hline 11. & Logam & Kuningan & 7250 \\
\hline 12. & Non-logam & Kaca & 2750 \\
\hline & & & \\
\hline
\end{tabular}

3. Buku Besar pengurus

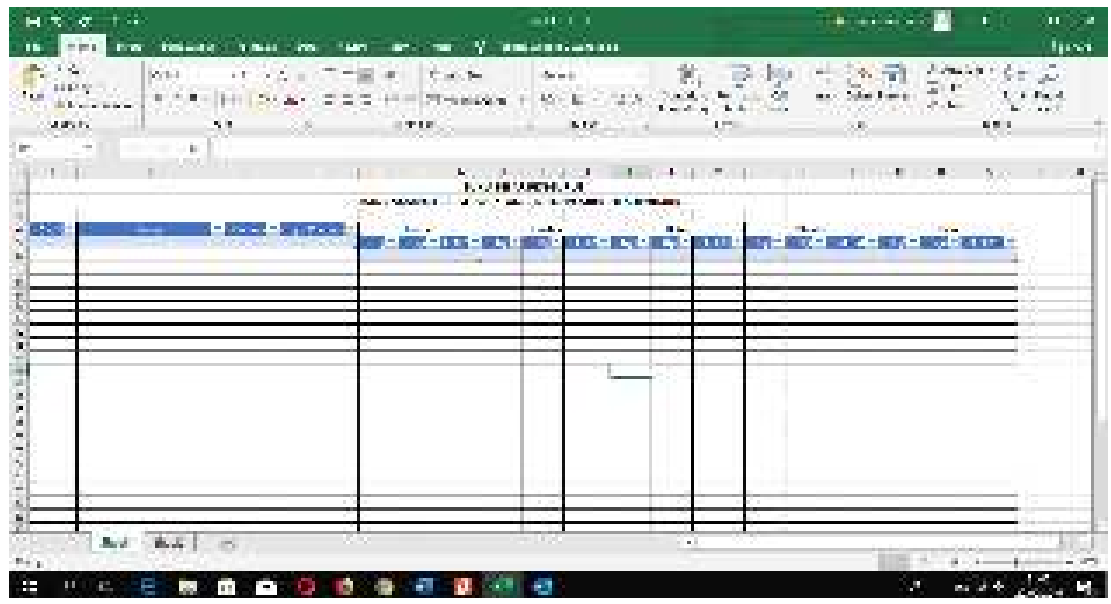

4. Buku Register Pengurus

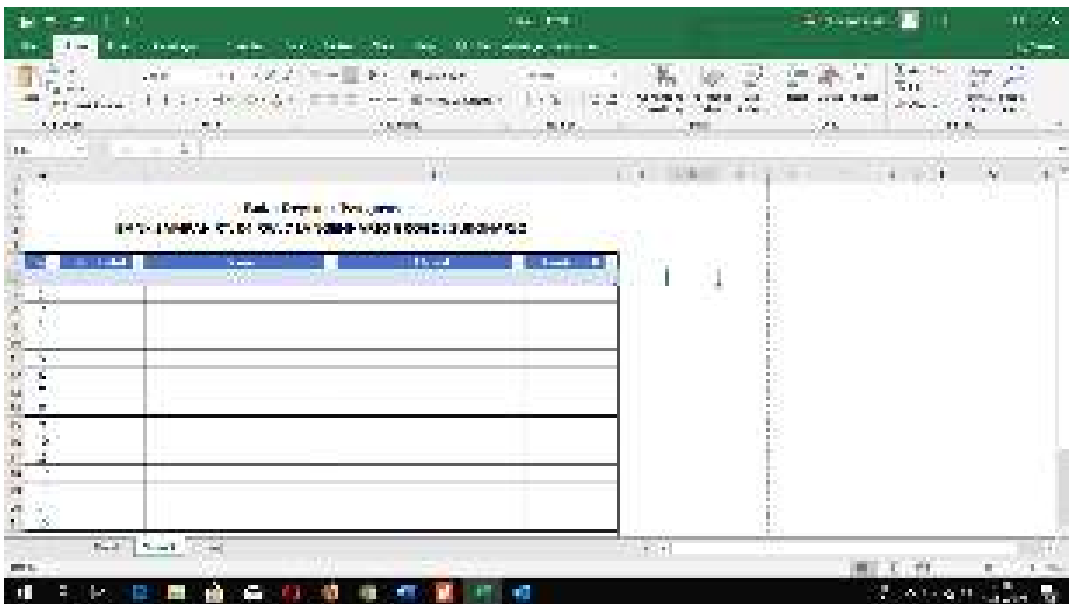


5. Buku Tabungan Nasabah

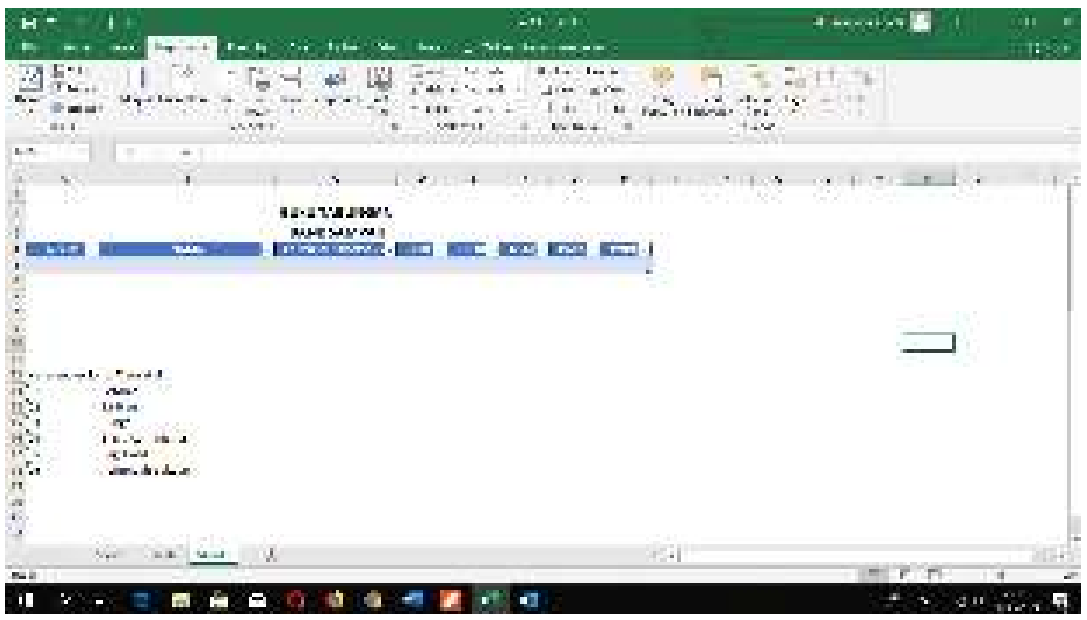

\section{HAMBATAN}

1. Anggota PKK RT 04 RW 07 Desa Langenharjo Kecamatan Grogol Sukoharjo hanya sebagian kecil yang antusias.

2. Sulit untuk merubah budaya dalam mengolah sampah.

3. Belum ada gambaran bagi anggota PKK untuk memulai mengelola sampah dengan menyetorkan dan mencatat administrasinya dengan bantuan aplikasi computer walaupun offline (program aplikasi Mirrosoft Excel).

4. Anggota PKK tidak tertarik menggunakan aplikasi manajemen sampah berbasis web.

5. Pencatatan administrasi manajemen sampah belum maksimal.

6. Kegiatan anggota dalam memilah, mengumpulkan dan menyetorkan sampah belum optimal.

\section{J. KESIMPULAN}

1. Mengolah sampah rumah tangga tidak mudah, dibutuhkan semangat yang sangat tinggi, disiplin dan empaty serta kepedulian terhadap lingkungan secara langsung.

2. Masih harus didampingi dalam mengadministrasikan manajemen setoran sampah

3. Anggota lebih memilih menggunakan aplikasi manajemen sampah dengan Microsoft excel yang offline

4. Kegiatan bank sampah sulit dilakukan jika tidak di support oleh pemerintah daerah dan bapak-bapak

\section{K. SARAN}

1. Pembinaan dan pendampingan adalah mutlak dilakukan.

2. Suport dari pemerintah daerah dan perusahaan sangat diharapkan.

3. Memberikan sarana dan prasarana kepada anggota PKK RT. 04 RW. 07 Langenharjo Grogol Sukoharjo.

4. Melibatkan anak muda, karang taruna sehingga administrasi manajemen sampah menjadi lebih efektif dan viral di kalangan anak muda. 


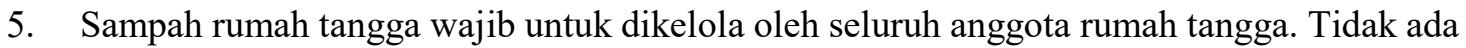
kata kompromi jika ingin budaya hidup bangsa akan merubah karakter bangsa, walau ini harus dilakukan dengan evolusi.

\section{DAFTAR PUSTAKA}

(C) Bibit Online. (2019). No Title. Retrieved from https://bibitonline.com/artikel/cara-praktis-membuatkompos-organik-sendiri

BPHN. (2008). PRESIDEN REPUBLIK INDONESIA DEWAN PERWAKILAN RAKYAT REPUBLIK INDONESIA dan PRESIDEN REPUBLIK INDONESIA. (1). Retrieved from www.bphn.go.id

Daftar isi Definisi Jenis-jenis. (n.d.).

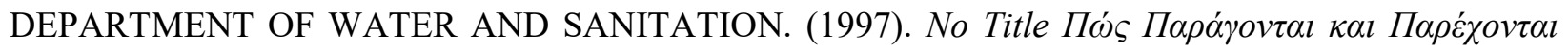

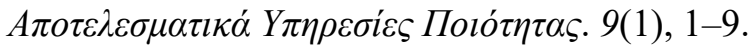

Fadhilah, A. (2011). Tata Cara Pengolahan Teknik Sampah Perkotaan. 11(2), 62-71. Retrieved from https://core.ac.uk/download/pdf/11731542.pdf

khafid muhamad, S. (2007). Fakultas Ekonomi Unnes Pengaruh Disiplin Belajar Dan Lingkungan Keluarga Terhadap Hasil Belajar Ekonomi. Jurnal Pendidikan Ekonomi Juli, 2(2), 185-204.

Pranadji, T. (2017). Penguatan Kelembagaan Gotong Royong dalam Perspektif Sosio Budaya Bangsa: Suatu Upaya Revitalisasi Adat Istiadat dalam Penyelenggaraan Pemerintahan. Forum Penelitian Agro Ekonomi, 27(1), 61. https://doi.org/10.21082/fae.v27n1.2009.61-72

Si, M. (2013). Potensi pemanfaatan sampah organik.

Silva, A. B. S. DA. (2012). Pengaruh Kompetensi dan Peranan Penyuluh Pertanian Terhadap Partisipasi Anggota Coperativa Cafe Organik dan Keberdayaan Petani Kopi.

Sunoko, riswan henna rya, \& Hadiyarto, A. (2011). Pengelolaan sampah rumah tangga di kecamatan daha selatan. Ilmu Lingkungan, 9.

سيادت سعيد. (n.d.). No Title

(C) Bibit Online. (2019). No Title. Retrieved from https://bibitonline.com/artikel/cara-praktis-membuatkompos-organik-sendiri

BPHN. (2008). PRESIDEN REPUBLIK INDONESIA DEWAN PERWAKILAN RAKYAT REPUBLIK INDONESIA dan PRESIDEN REPUBLIK INDONESIA. (1). Retrieved from www.bphn.go.id

Daftar isi Definisi Jenis-jenis. (n.d.).

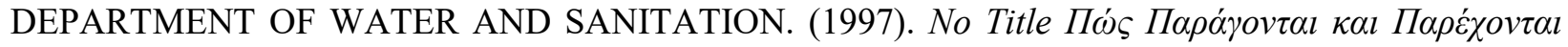

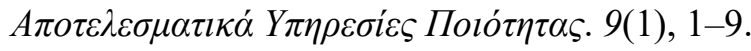

Fadhilah, A. (2011). Tata Cara Pengolahan Teknik Sampah Perkotaan. 11(2), 62-71. Retrieved from https://core.ac.uk/download/pdf/11731542.pdf

khafid muhamad, S. (2007). Fakultas Ekonomi Unnes Pengaruh Disiplin Belajar Dan Lingkungan Keluarga Terhadap Hasil Belajar Ekonomi. Jurnal Pendidikan Ekonomi Juli, 2(2), 185-204.

Pranadji, T. (2017). Penguatan Kelembagaan Gotong Royong dalam Perspektif Sosio Budaya Bangsa: Suatu Upaya Revitalisasi Adat Istiadat dalam Penyelenggaraan Pemerintahan. Forum Penelitian Agro Ekonomi, 27(1), 61. https://doi.org/10.21082/fae.v27n1.2009.61-72

Si, M. (2013). Potensi pemanfaatan sampah organik.

Silva, A. B. S. DA. (2012). Pengaruh Kompetensi dan Peranan Penyuluh Pertanian Terhadap Partisipasi Anggota Coperativa Cafe Organik dan Keberdayaan Petani Kopi. 


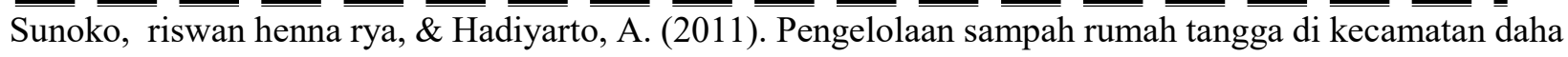
selatan. Ilmu Lingkungan, 9.

سيادت سعيد. (n.d.). No Title $\square \square \square \square \square \square \square \square \square$.

Sunoko, riswan henna rya, \& Hadiyarto, A. (2011). Pengelolaan sampah rumah tangga di kecamatan daha selatan. Ilmu Lingkungan, 9.
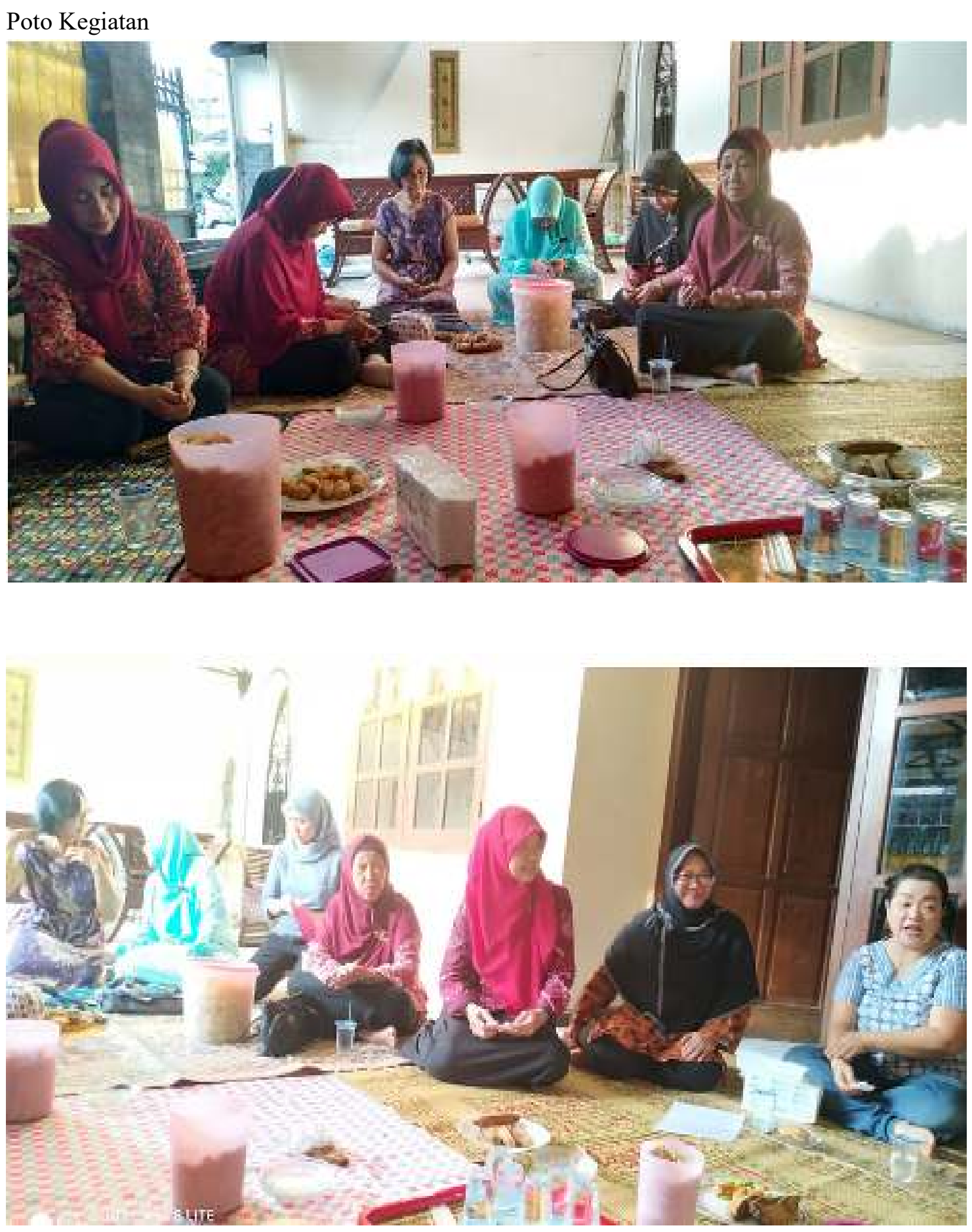

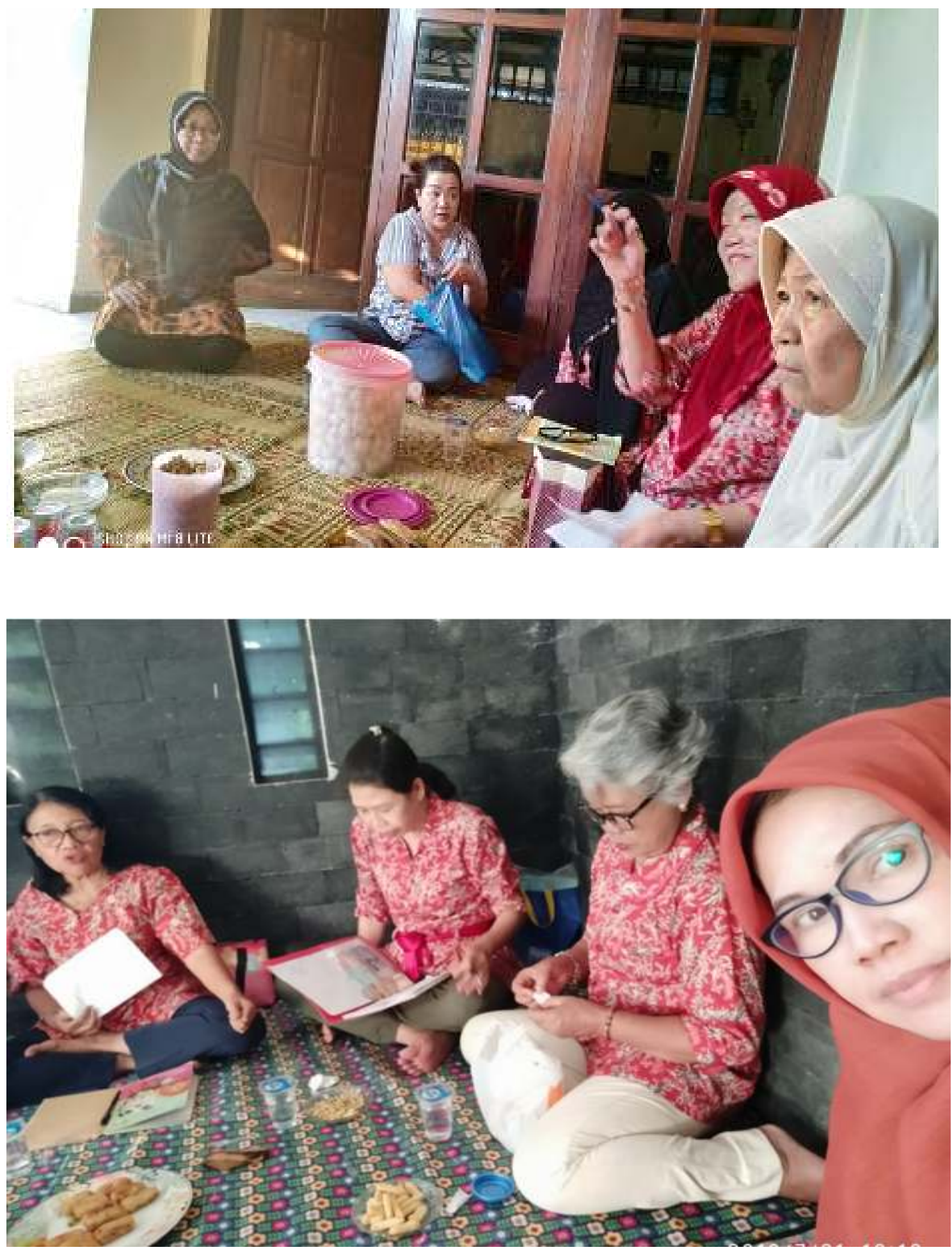